\title{
SPECIFIC DYNAMIC ACTION OF CARBOHYDRATE AND OF PROTEIN IN HUMAN HYPOTHYROIDISM AFTER \\ TOTAL ABLATION OF THE NORMAL THYROID GLAND ${ }^{1}$
}

\author{
Bx MILTON LANDOWNE \\ (From the Medical Research Laboratories of the Beth Israel Hospital and the Department of \\ Medicine, Harvard Medical School, Boston)
}

(Received for publication May 15, 1935)

The effect of hypothyroidism on the specific dynamic action of carbohydrate and of protein in man and in animals has been previously studied by several investigators. The results of these studies and their interpretations vary.

In a group of patients at this hospital hypothyroidism has been induced by total ablation of the normal thyroid gland for the treatment of chronic heart disease (1) (2). An opportunity was thereby presented to reinvestigate the effect of hypothyroidism upon the specific dynamic action in man. Total thyroidectomy was performed in these patients in order that in the hypothyroid state they might derive the benefits of the lessened demands upon the heart (2) (3) (4). It seemed important to establish whether or not these individuals, in addition, were relieved of the increased demands upon the circulatory system coincident to increased metabolism after the ingestion of food.

\section{REVIEW OF LITERATURE}

In human hypothyroidism the specific dynamic action of carbohydrate has been reported in two cases. DuBois (5) in 1916, using continuous calorimetry studied the metabolism in a cretin whose basal metabolic rate was minus 20 per cent. From the first through the fourth hour after the ingestion of 100 grams of lactose, and upon another. occasion, after the ingestion of 70 grams of dextrose, there occurred an average increase in heat production of 15 per cent above the basal value following the lactose, and of 7 per cent following the dextrose. These increases were similar to those observed by DuBois in normal individuals.

1 This investigation was aided by a grant from the William W. Wellington Memorial Research Fund of Harvard University.
Weisz and Adler (6) in 1922, measured the oxygen consumption up to three hours after 100 grams of cane sugar. were ingested by a patient with myxedema who was being treated with thyroid. Nine experiments were reported, performed at basal oxygen consumptions corresponding to basal metabolic rates of approximately minus 15 to plus 18 per cent; the lowest basal metabolic rates were approximately minus 15 , minus 15 , and minus 3 per cent. In the two experiments performed when the basal metabolic rates were minus 15 per cent the average increases in oxygen consumption after sugar amounted to 13 per cent and 9 per cent of the basal values. In seven of the nine experiments the average deviation of the total increase from the mean was \pm 4 per cent, the basal metabolism in these seven instances varying between minus 15 and plus 18 per cent. If specific dynamic action be expressed as total increase in oxygen consumption, then these experiments show almost constant specific dynamic action as the basal metabolic rate is varied; in terms of percentage increase the specific dynamic action is larger at the lower. metabolic levels.

Several investigators have studied the specific $d y$ namic action of protein in human hypothyroidism and all of these have found a resultant increase in metabolism. DuBois (5) observed an increase of heat production of 13 per cent from the second through the sixth hour after a protein meal given to the cretin subject referred to above. Grafe (7) studied the respiratory exchange for eleven hours after the ingestion of a protein meal by a sixteen year old obese hypothyroid girl (basal metabolic rate, minus 20 per cent). The increases in metabolism observed were interpreted as normal.

Other workers have reported the changes in 
metabolism for periods of only one to two and one-half hours after the administration of a protein test meal (8) (9) (10). Since the metabolic increases for the amounts of protein employed in these instances may well be expected to last over six hours (11), one can not conclude as to the total specific dynamic action in these experiments. In two of these investigations (8) (9), the specific dynamic action was expressed as the percentage increase in metabolism observed at one particular determination, at one or at one and onehalf hours after the meal. These values give no indication of the total or average metabolic increase. Plaut (12) (13) also observed an increase in metabolism in patients with hypothyroidism during three hours after protein ingestion. The interpretation of the results of these experiments is complicated by the fact that $500 \mathrm{cc}$. of coffee were included in the test meals (14) (15).

The results and conclusions from studies of the specific dynamic action of carbohydrate and of protein in animals after thyroidectomy differ. Baumann and Hunt (16) found that glucose administered to ten rabbits upon which thyroidectomy had been performed resulted in no increase in metabolism or in a smaller increase than was observed after glucose in the same animals preoperatively, or in nonoperated controls. Oxygen and carbon dioxide exchange and total calories were reported over a period of two hours before and over a period of four hours after the glucose was administered. Mansfeld and Scheffer-Csillag (17) conclude that thyroidectomy had no influence on the specific dynamic action of meat or of sugar in two dogs. Hertz (18) denies an influence of thyroidectomy on specific dynamic action of protein in dogs. His conclusions are based upon measurements made at about three and seven hours after feeding meat together with rice and fat to a single thyroidectomized dog. Årvay and Verzár (19) (20) studied the specific dynamic action in thyroidectomized rats over periods of from six to eight hours after feeding meat. They reported a decreased specific dynamic action up to thirty-six days after operation. Dann, Chambers, and Lusk (21) found that their figures in a single experiment incidental to another problem " might suggest that the specific dynamic action of meat is less after thyroidectomy than in the normal dog. ..." Houssay and Artundo (22) found that the specific dynamic action, expressed as increase in heat production, measured two and five hours after administering meat to dogs was slightly less after thyroidectomy (6 experiments), and after thyrohypophysectomy ( 7 experiments), than in controls (10 experiments) but they conclude that the hypophysis and thyroid are not necessary for the production of specific dynamic action.

Due to the usual presence of aberrant thyroid tissue, it is difficult to produce persistent hypothyroidism in animals. In some of the experiments on thyroidectomized animals reported above (16) (17) hypothyroidism as evidenced by a low control metabolic level was not present at all times when specific dynamic action was tested.

\section{MATERIALS AND METHODS}

Total ablation of the thyroid gland had been performed on the subjects of the present investigation for the treatment of angina pectoris or of rheumatic heart disease (1) (2). Measurements of specific dynamic action were made from two weeks to twenty-one months postoperatively. In two patients experiments were performed preoperatively, one of these patients being tested again two weeks postoperatively and the other two months after operation. Fourteen carbohydrate experiments were performed in eleven patients and five protein experiments in four patients. The metabolism of three of the patients was also measured over a period of five hours without food. The average basal metabolic rate at the time of the postoperative measurements of specific dynamic action was minus 28 per cent. The subjects were from eighteen to sixty-five years of age. All of the patients were maintaining a practically constant body weight; one was obese (E. P.), the others were well developed. Signs or symptoms of congestive heart failure were not present at the time of the tests, nor were anginal attacks experienced just prior to or during any of the experiments. The subjects of eight experiments were taking thyroid (grains $1 / 10$ to $1 / 2$ daily, Armour) to maintain them free from discomforting symptoms of myxedema; and one patient (M. S.) had $150 \mathrm{mgm}$. of dinitrophenol on the day prior to the test.

All subjects were well trained in metabolism tests. They came to the laboratory from home or from the hospital wards in the morning in the postabsorptive state, without medication, and in some cases having omitted thyroid on the preceding day. After the patient had rested at least thirty minutes either flat in bed or slightly raised, a determination of oxygen consumption was made for a period of seven minutes using a Collins BenedictRoth apparatus. Three to five such measurements (usually four, consisting of two determinations in duplicate) 
were made over about one hour in order to obtain a control period; following this, the carbohydrate or protein meal was administered.

In the carbohydrate tests fifty to seventy-five grams of glucose were ingested dissolved in 200 grams of orange juice and heated to approximately $36^{\circ} \mathrm{C}$. The meals totalled 280 to 375 calories (the caloric value of $1 \mathrm{gram}$ of hexose is 3.74 calories). Measurements of oxygen consumption were begun fifteen minutes after the ingestion and continued, at intervals, for two to three and one-half hours, a total of six to nine measurements being made after the meal. When duplicate measurements did not check or seemed erratic, additional measurements were made. The results obtained were plotted noting each observation upon the graph. From smoothed curves through the points obtained the oxygen consumption at $1 / 4,1 / 2,1,11 / 2$, and 2 hours were tabulated.

In the protein tests from 200 to $\mathbf{4 0 0}$ grams of steak, with small amounts of added protein, fat, and carbohydrate (54 to 102 grams $P, 25$ to 44 grams F, 6 to 23 grams $\mathrm{CHO}=\mathbf{5 2 0}$ to 860 calories) were ingested after the control level of metabolism was determined. The average protein intake was 77 grams, the average total calories 685. The oxygen consumption was followed at hour after smoking are not held trustworthy (23). If the measurements following the smoking be omitted in drawing the course of the oxygen consumption, the actual points thirty minutes after smoking are $0,0,6$, and 5 per cent above the curves thus obtained.

The procedures were not discomforting but not enjoyable, and in three cases the subjects asked as to how soon the test would be finished. Only one subject (E. P.) could be considered uncooperative. A tendency to drowsiness was almost universal, but most of the subjects remained quietly awake. The more intelligent patients were told something of the nature of the test; others merely followed instructions. The low metabolic rates, experience with the apparatus, and almost universal willingness to cooperate, all helped to maintain the subjects at ease.

\section{RESULTS}

\section{Specific dynamic action of glucose}

The results of eleven experiments on nine patients, two to twenty-one months after total thyroidectomy, are presented in Table I. Two stud-

TABLE I

Specific dynamic action of carbohydrate after total thyroidectomy

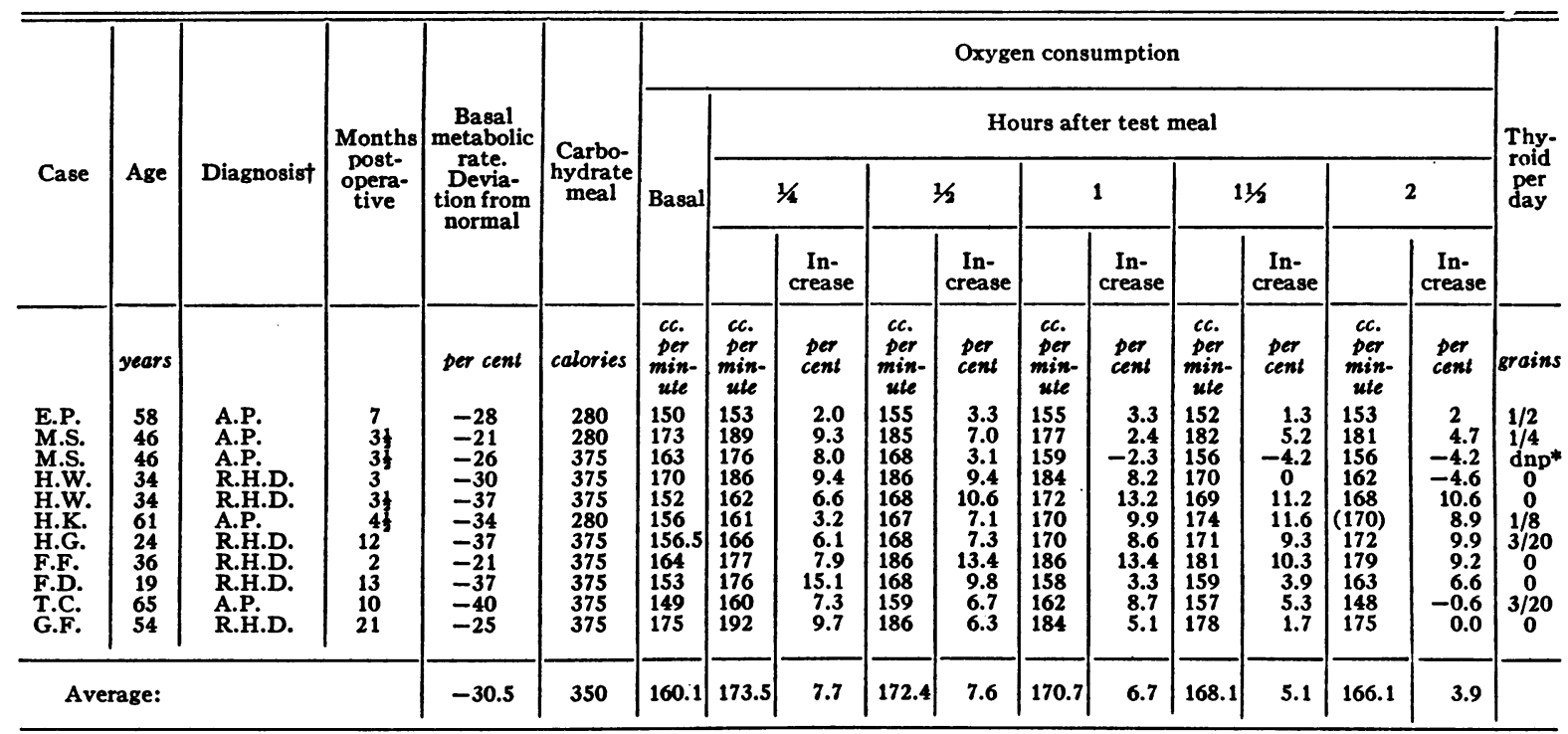

* $150 \mathrm{mgm}$. dinitrophenol on day preceding test.

t Diagnoses: A.P. = Angina pectoris; R.H.D. = Rheumatic heart disease.

intervals for six to seven hours afterwards, measurements being made in duplicate, and the results of each measurement were plotted. One subject had three puffs on a cigar, another had a cigarette directly after the meal; two subjects each had a cigarette five hours after the meal. Not knowing whether smoking or its denial would vitiate results more, the effort was made to keep the patient at ease. Measurements made within a half ies are not included because of our inability to obtain check measurements. Another experiment was performed only two weeks after operation and is referred to later. The oxygen consumption per minute at one-fourth, one-half, one, one and a half, and two hours were obtained as described above. The percentage increase in oxy- 
gen consumption over the basal at each point has also been calculated (Table $I$ ). The averages of the values for oxygen consumption in Table $I$ are plotted as the lower curve in Figure 1. The total
The average basal metabolic rate at the time of the glucose experiments was minus 30.5 per cent, the range was from minus 21 to minus 40 per cent (Table I). The maximal increase in oxygen

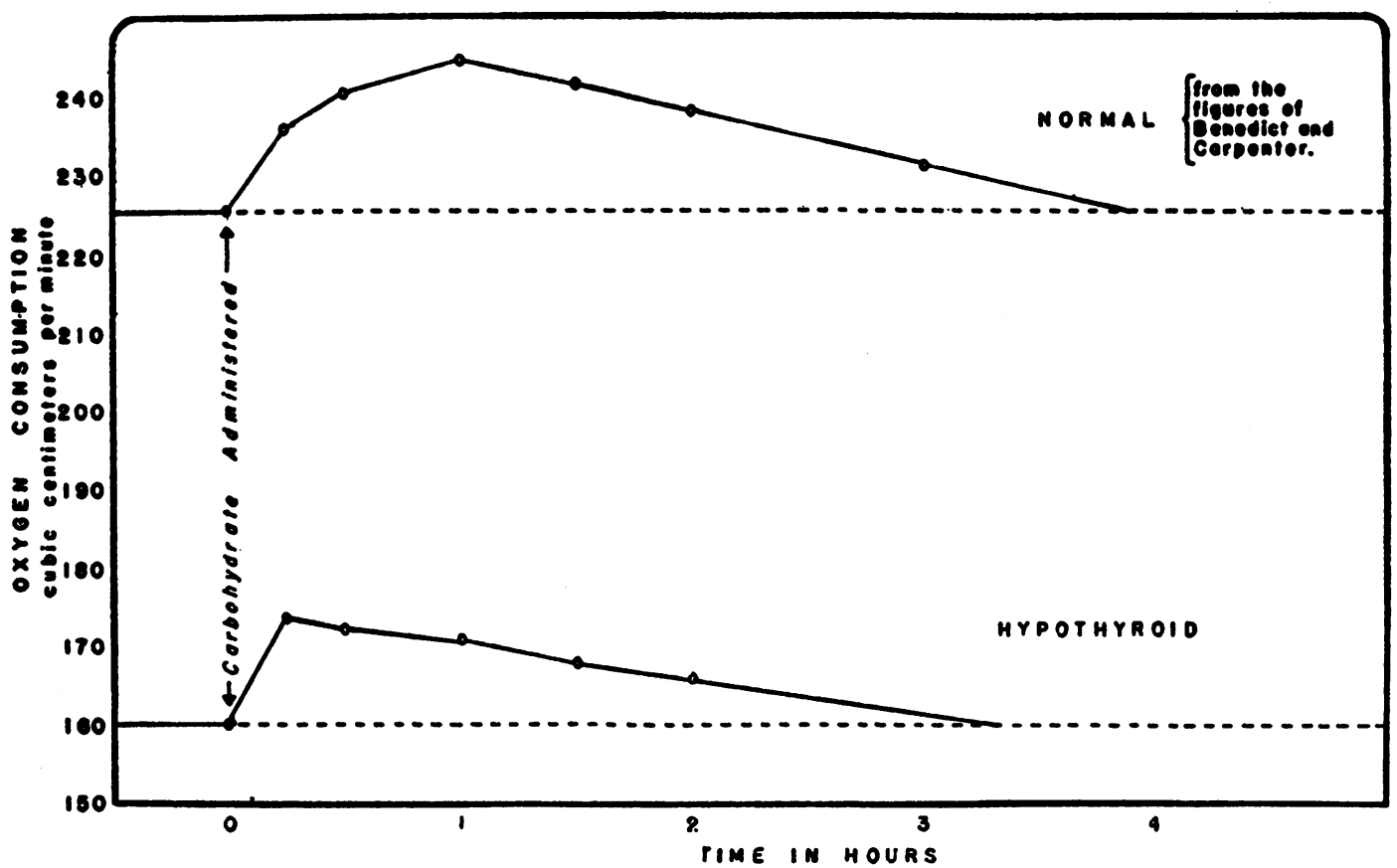

Fig. 1. Change in Rate of Oxygen Consumption After the Ingestion of 75 to 100 Grams of CARBoHydrate.

Lower curve. Average of eleven experiments upon patients with hypothyroidism. Upper curve. Average of twelve experiments by Benedict and Carpenter (11) upon normal individuals.

increases in oxygen consumption or the areas under the curves above the control levels have been calculated for the arbitrary period of two hours and for the actual or extrapolated duration of the increases. The average, the maximal, and the minimal increases and the corresponding percentage increases are listed in Table II. consumption after the glucose in the different experiments ranged from 3.3 to 15.1 per cent of the basal oxygen consumption (average 10.1 per cent). This maximal increase occurred at onequarter hour after the test meal in five cases, onehalf hour in two cases, one hour in two cases, one and one-half hours and two hours in one case

TABLE II

Summary of specific dymamic action after carbohydrate ingestion

\begin{tabular}{|c|c|c|c|c|c|c|c|c|c|c|c|}
\hline & $\begin{array}{c}\begin{array}{c}\text { Carbo- } \\
\text { hydrate } \\
\text { meal }\end{array} \\
\text { calories }\end{array}$ & $\begin{array}{c}\begin{array}{c}\text { Basal meta- } \\
\text { bolic rate. } \\
\text { Deviation } \\
\text { from } \\
\text { normal }\end{array} \\
\text { per cent }\end{array}$ & $\begin{array}{c}\begin{array}{c}\text { Basal } \\
\text { oxygen } \\
\text { consump- } \\
\text { tion }\end{array} \\
\begin{array}{c}c c \text { per } \\
\text { minute }\end{array}\end{array}$ & \multicolumn{2}{|c|}{ 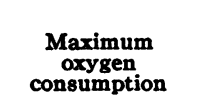 } & \multicolumn{2}{|c|}{$\begin{array}{l}\text { Increase in oxy- } \\
\text { gen consumption } \\
\text { for two hours }\end{array}$} & \multicolumn{2}{|c|}{$\begin{array}{l}\text { Total increase } \\
\text { in oxygen } \\
\text { consumption }\end{array}$} & \multirow{2}{*}{$\begin{array}{c}\begin{array}{c}\text { Extra } \\
\text { calories } \\
\text { (R.Q. 0.88) }\end{array} \\
\\
\\
6.8 \\
15.9 \\
3.8\end{array}$} & \multirow{2}{*}{$\begin{array}{c}\begin{array}{c}\text { "Cost" } \\
\text { (extra } \\
\text { calories per } \\
\text { 100 calories } \\
\text { ingested) }\end{array} \\
\\
1.9 \\
4.2 \\
1.4\end{array}$} \\
\hline $\begin{array}{l}\text { Average . . . . . } \\
\text { Maximum } \\
\text { Minimum } \ldots \ldots\end{array}$ & $\begin{array}{c}\text { calories } \\
350 \\
375 \\
280\end{array}$ & $\begin{array}{l}\text { per cent } \\
-30.5 \\
-21 \\
-28\end{array}$ & $\begin{array}{l}\text { cc. per } \\
\text { minute } \\
160.1 \\
164 \\
150\end{array}$ & $\begin{array}{l}c c . \text { per } \\
\text { minute } \\
174 \\
188 \\
156.5\end{array}$ & $\begin{array}{r}\text { increase } \\
\text { per cent } \\
8.75 \\
14.64 \\
4.33\end{array}$ & $\begin{array}{c}c c . \\
1160 \\
2138 \\
540\end{array}$ & $\begin{array}{c}\text { per } \\
\text { cent } \\
6.0 \\
10.8 \\
4.5\end{array}$ & $\begin{array}{c}c c . \\
1400 \\
3300 \\
780\end{array}$ & $\begin{array}{c}\text { per } \\
\text { cent } \\
4.4 \\
7.4 \\
3.3\end{array}$ & & \\
\hline
\end{tabular}

* Experiment 1 (E.P.) in Table I-(From Table I; experiment 3 (M.S.) gives a smaller increase, but due to apparent negative values this finding is questionable). 
each. The maximal increase of the average curve was 8.7 per cent, the increase over two hours was $1160 \mathrm{cc}$. or 6 per cent; the total increase was 1400 cc. or 4.4 per cent (over 3 and $1 / 3$ hours). Assuming an average R.Q. of $0.875^{2}$ after the food there were 6.8 extra calories produced or $1.9 \mathrm{cal}-$ ories for every 100 calories from carbohydrate ingested. The results of experiments in two subjects performed both before and after operation are presented in Table III. In both of these sub-

\section{Control measurements of metabolism without test meal}

The oxygen consumption in Patient G. F. fluctuated during four hours by \pm 2.7 per cent from a level of $165 \mathrm{cc}$. of oxygen per minute. Four weeks previously during the one hour control period before a protein meal the oxygen consumption decreased from $171 \mathrm{cc}$. to $167 \mathrm{cc}$. per minute. The oxygen consumption in Patient W. D. decreased progressively during four hours

TABLE III

Summary of specific dynamic action of carbohydrate in subjects studied both before and after operation

\begin{tabular}{|c|c|c|c|c|c|c|c|c|c|}
\hline & \multirow{2}{*}{$\begin{array}{c}\begin{array}{c}\text { Basal } \\
\text { metabolic } \\
\text { rate. } \\
\text { Deviation } \\
\text { from } \\
\text { normal }\end{array} \\
\text { per cent }\end{array}$} & \multirow{2}{*}{$\begin{array}{c}\begin{array}{c}\text { Carbo- } \\
\text { hydrate } \\
\text { meal }\end{array} \\
\text { calories }\end{array}$} & \multicolumn{2}{|c|}{$\begin{array}{c}\text { Maximum } \\
\text { increase } \\
\text { in oxygen } \\
\text { consumption }\end{array}$} & \multicolumn{2}{|c|}{$\begin{array}{c}\text { Increase } \\
\text { in oxygen } \\
\text { consumption } \\
\text { over two hours }\end{array}$} & \multicolumn{2}{|c|}{$\begin{array}{c}\text { Total } \\
\text { increase } \\
\text { in oxygen } \\
\text { consumption }\end{array}$} & \multirow[t]{2}{*}{$\begin{array}{c}\text { “Cost" } \\
\text { (extra } \\
\text { calories } \\
\text { per 100 } \\
\text { calories } \\
\text { ingested) }\end{array}$} \\
\hline & & & $\begin{array}{l}c c . \text { per } \\
\text { minute }\end{array}$ & per cent & $c c$. & per cent & $c c$. & per cent & \\
\hline $\begin{array}{l}\text { R.S. - preoperative } \ldots \ldots \\
2 \text { weeks postoperative } \ldots \ldots\end{array}$ & $\begin{array}{l}+8 \\
-13\end{array}$ & $\begin{array}{l}280 \\
375\end{array}$ & $\begin{array}{l}30 \\
52\end{array}$ & $\begin{array}{l}11.5 \\
24\end{array}$ & $\begin{array}{l}2160 \\
3960\end{array}$ & $\begin{array}{r}7 \\
15\end{array}$ & $\begin{array}{l}2160 \\
4010\end{array}$ & $\begin{array}{r}7 \\
14\end{array}$ & $\begin{array}{l}3.8 \\
5.2\end{array}$ \\
\hline $\begin{array}{l}\text { F.F.-preoperative. } \ldots \ldots \ldots \\
2 \text { months postoperative. . }\end{array}$ & $\begin{array}{l}-9 \\
-21\end{array}$ & $\begin{array}{l}375 \\
375\end{array}$ & $\begin{array}{l}12 \\
22\end{array}$ & $\begin{array}{r}6.3 \\
13.4\end{array}$ & $\begin{array}{l}1200 \\
2180\end{array}$ & $\begin{array}{r}5.3 \\
11.1\end{array}$ & $\begin{array}{l}1440 \\
3284\end{array}$ & $\begin{array}{l}4.3 \\
7.3\end{array}$ & $\begin{array}{l}1.9 \\
4.3\end{array}$ \\
\hline
\end{tabular}

* This experiment was not included in Table I or Table II ., because only two weeks had elapsed since operation.

jects the specific dynamic action was higher in the experiments after operation than before.

\section{Specific dynamic action of protein}

The results in five experiments on the four patients are summarized in Table IV. One-half hour after the administration of the protein test meal a rise in oxygen consumption was observed. The oxygen consumption reached its average maximum between one-half and three hours after the meal and remained at about that level for the duration of the experiment ( 6 to $7 \frac{1}{2}$ hours). From the curves plotted as described the average total increase during the experiments was 10,570 cc., equivalent to approximately fifty extra calories or to an average increase of 16.6 per cent over the basal oxygen consumption. The caloric increase was 7 per cent of the caloric intake or 17 per cent of the protein calories ingested. The average basal metabolic rate for this series was minus 28.6 per cent.

2 The average respiratory quotient from 0 to 3 hours after dextrose in the experiments of Benedict and Carpenter was 0.875 (11). from 182 to 167 cc. per minute. In an experimental control one week later the oxygen consumption decreased from 187 to $180 \mathrm{cc}$. per minute in one hour and again two weeks later from 185 to $182 \mathrm{cc}$. per minute in one hour. The oxygen consumption in Patient F. D. during the first hour was $130 \mathrm{cc}$. per minute $\pm 15 \mathrm{cc}$. (11.5 per cent). From then through the fourth hour the oxygen consumption remained $130 \mathrm{cc} . \pm 5 \mathrm{cc}$. (3.8 per cent). In an experimental control one week previously the oxygen consumption was 145 cc. per minute $\pm 2 \mathrm{cc}$. ( 1.4 per cent) over threequarters of an hour.

\section{DISCUSSION}

The purpose of the above study was to discover whether the specific dynamic action of carbohydrate and of protein in patients with hypothyroidism following total thyroidectomy differed significantly from that reported for normal individuals. The method of studying specific dynamic action which has been utilized above was chosen because of its simplicity and because early experiences showed it to be suitable to our pur- 
TABLE IV

Summary of specific dynamic action after protein ingestion

\begin{tabular}{|c|c|c|c|c|c|c|c|c|c|c|c|c|c|c|c|c|c|}
\hline \multirow{2}{*}{ Case } & \multirow{2}{*}{ Age } & \multirow{2}{*}{ Diagnosis } & \multirow{2}{*}{$\begin{array}{c}\text { Months } \\
\text { post- } \\
\text { opera- } \\
\text { tive }\end{array}$} & \multicolumn{2}{|c|}{ Test meal } & \multirow{2}{*}{$\begin{array}{c}\text { Basal } \\
\text { metabolic } \\
\text { rate. } \\
\text { Devia- } \\
\text { tion from } \\
\text { normal }\end{array}$} & \multicolumn{2}{|c|}{$\begin{array}{c}\text { Oxygen } \\
\text { consumption }\end{array}$} & \multicolumn{2}{|c|}{$\begin{array}{l}\text { Maximum } \\
\text { increase } \\
\text { over basal }\end{array}$} & \multirow{2}{*}{$\begin{array}{c}\text { Time } \\
\text { to } \\
\text { reach } \\
\text { maxi- } \\
\text { mum }\end{array}$} & \multirow{2}{*}{$\begin{array}{l}\text { Dura- } \\
\text { tion of } \\
\text { approx- } \\
\text { imate } \\
\text { maxi- } \\
\text { mum } \\
\text { increase }\end{array}$} & \multirow{2}{*}{\multicolumn{2}{|c|}{$\begin{array}{c}\text { Total } \\
\text { increase } \\
\text { in oxygen } \\
\text { consumption }\end{array}$}} & \multirow{2}{*}{\multicolumn{2}{|c|}{$\begin{array}{c}\text { Increase } \\
\text { in oxygen } \\
\text { per } 100 \\
\text { grams } \\
\text { protein }\end{array}$}} & \multirow{2}{*}{$\begin{array}{l}\text { Thy- } \\
\text { roid } \\
\text { per } \\
\text { day }\end{array}$} \\
\hline & & & & $\begin{array}{l}\text { Pro- } \\
\text { tein }\end{array}$ & $\begin{array}{c}\text { Total } \\
\text { cal- } \\
\text { ories }\end{array}$ & & Basal & $\mid \begin{array}{l}\text { Ap- } \\
\text { proxi- } \\
\text { mate } \\
\text { maxi- } \\
\text { mum }\end{array}$ & Total & $\mid \begin{array}{c}\text { rer } \\
100 \\
\text { grams } \\
\text { pro- } \\
\text { tein }\end{array}$ & & & & & & & \\
\hline & years & & & grams & & per cent & $\begin{array}{l}c c \text { per } \\
\text { minute }\end{array}$ & $\left|\begin{array}{l}c c . \text { per } \\
\text { minute }\end{array}\right|$ & $\begin{array}{c}\text { per } \\
\text { cent }\end{array}$ & $\begin{array}{l}\text { per } \\
\text { cent }\end{array}$ & hours & hours & $c c$. & $\begin{array}{l}\text { per } \\
\text { cent }\end{array}$ & $c c$. & $\left|\begin{array}{c}\text { per } \\
\text { cent }\end{array}\right|$ & grains \\
\hline $\begin{array}{l}\text { G.F. } \\
\text { W.D. } \\
\text { W.D. } \\
\text { F.D. } \\
\text { S.F. }\end{array}$ & $\begin{array}{l}53 \\
23 \\
23 \\
18 \\
53\end{array}$ & $\begin{array}{l}\text { R.H.D. } \\
\text { R.H.D. } \\
\text { R.H.D. } \\
\text { R.H.D. } \\
\text { A.P. }\end{array}$ & $\begin{array}{r}12 \\
9 \\
9 \\
4 \\
10\end{array}$ & $\begin{array}{r}102 \\
54 \\
56 \\
70 \\
102\end{array}$ & $\begin{array}{l}860 \\
520 \\
600 \\
620 \\
825\end{array}$ & $\begin{array}{l}-27 \\
-25 \\
-21 \\
-38 \\
-32\end{array}$ & $\mid \begin{array}{c}168 \\
180-170 * \\
180-170^{*} \\
145 \\
159\end{array}$ & $\begin{array}{l}208 \\
198 \\
190 \\
168 \\
212\end{array}$ & $\begin{array}{l}24 \\
16 \\
12 \\
16 \\
33\end{array}$ & $\begin{array}{l}24 \\
30 \\
21 \\
23 \\
33\end{array}$ & $\begin{array}{l}2 \\
\frac{3}{4} \\
3 \\
\frac{1}{2} \\
2 \frac{1}{2}\end{array}$ & $\begin{array}{l}7 \frac{1}{2} \\
6 \\
7 \frac{1}{2} \\
7 \\
6\end{array}$ & $\begin{array}{r}11,240 \\
10,440 \\
8,400 \\
7,475 \\
14,300\end{array}$ & $\begin{array}{l}17 \\
16 \\
11 \\
14 \\
25\end{array}$ & $\begin{array}{l}11,030 \\
19,350 \\
14,850 \\
10,500 \\
14,100\end{array}$ & $\begin{array}{l}16 \\
30 \\
20 \\
20 \\
25\end{array}$ & $\begin{array}{l}0 \\
1 / 8 \\
1 / 8 \\
1 / 3 \\
1 / 10\end{array}$ \\
\hline \multicolumn{4}{|c|}{ Average } & 77 & 685 & -28.6 & 166 & 195 & 20 & 26 & & & 10,570 & 17 & 14,000 & 22 & \\
\hline
\end{tabular}

* During a control experiment without food the oxygen consumption of this patient fell from 182 to 167 cc. in four hours. The experimental controls over one hour before the test meals likewise showed a slight progressive fall in oxygen consumption (see text).

pose. In the well trained subjects in this investigation the error with which the oxygen consumption over six minutes could be measured by a Benedict-Roth apparatus was 3 per cent or less. Obviously, the results over the entire experimental period are not as accurate as could be obtained by continuous calorimetry, but by the use of duplicate and serial determinations they are sufficiently precise to render the interpretations valid.

It would have been theoretically more desirable to use a group of patients who were not taking any thyroid, and whose metabolic rates were even lower and symptoms of myxedema even more pronounced than in the present series. No consistent difference in specific dynamic action could be found, however, between the results in those patients who were taking thyroid (grains 1/10 to $1 / 2$ daily) and in the patients to whom no thyroid was being given. In addition, the nature of the response of oxygen consumption after the administration of sugar was not correlated with the basal oxygen consumption or the "basal metabolic rate."

A consistent increase in oxygen consumption occurred in all experiments (Table I) following the administration of carbohydrate. The increase in oxygen consumption is interpreted as resulting from the ingestion of carbohydrate, for the amount of fluid administered was insufficient to affect the metabolism (11) and in many cases a return to basal oxygen level occurred within two to three hours after the meal.
Many methods of expressing specific dynamic action have been utilized. The data of our experiments allow calculation in absolute and percentage values on the basis of maximal oxygen increase, total and average increase over two hours, and over the extrapolated duration of the increase; in the carbohydrate tests the results may be expressed in addition, as total extra calories, and extra calories per hundred grams of carbohydrate, by assuming a respiratory quotient of 0.88 with an error of \pm 2.5 per cent.

Our data calculated in these several ways are compared with similarly treated values for oxygen consumption from the experiments of Benedict and Carpenter (11) and of Gephart and DuBois (24) for the specific dynamic action of glucose in subjects with normal metabolic levels ('Table V). Previous to operation, not only were most patients insufficiently trained in the technique of metabolism testing but their clinical conditions would not permit of satisfactory determinations of specific dynamic action. It was felt, therefore, that the results of other authors using well trained subjects with normal metabolic levels would serve as a more accurate basis for comparisons with the present series. From Benedict and Carpenter's work (11) are taken nine experiments in which 100 grams of glucose were given and three experiments in which 75 grams were given; in all, twelve experiments on ten subjects. From Gephart and DuBois (24) six experiments upon three patients are reported. The average maximal in- 


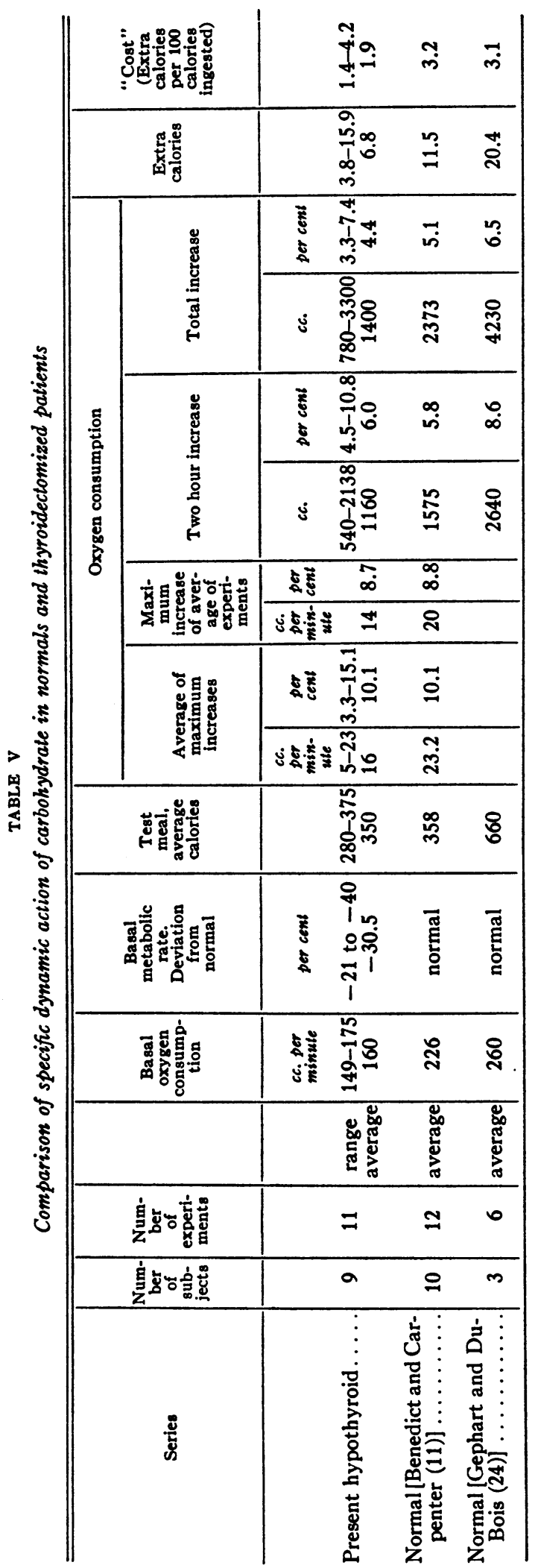

crease, the two hour increment, and the total increment in oxygen consumption after carbohydrate in the present series is less than in the control series of 'normals but the range of results overlaps. The average percentage maximal increase and percentage two hourly increase are essentially the same in both the normal and thyroidectomized subjects. The average percentage increase over the entire duration of the increase is approximately the same in our series as in the series of Benedict and Carpenter (11), but is slightly less as compared to the figures of Gephart and DuBois (24) who administered more sugar (Table V). Calculated as extra calories expended for 100 calories of food (assuming an R.Q. of 0.88 ) the average specific dynamic action in our patients is somewhat less than in both series of the controls, but again the results in individual instances overlap. The carbohydrate experiments performed on two of our patients both before and after operation show in each case a greater specific dynamic action following thyroidectomy (Table III). It is to be noted, however, that these postoperative experiments were done only two weeks and two months after operation. The basal metabolic rates of the two patients with hypothyroidism on whom specific dynamic action studies after carbohydrate were made by DuBois (5) and by Weisz and Adler (6) were only reduced to minus 20 per cent (5) and minus 15 per cent (6) at the time of the tests. In these instances, as in our patients with lower basal metabolic rates, the results obtained were not different from those obtained in some normal individuals.

There is no apparent statistical correlation between the basal rates of oxygen consumption and the total increase in oxygen consumption per 100 grams of ingested sugar as calculated from the combined experiments of Weisz and Adler (6), Benedict and Carpenter (11) Gephart and DuBois (24) and the present series. The coefficient of correlation of these thirty-eight determinations of specific dynamic action in normals and hypothyroids is plus .2 (a perfect correlation would be either plus or minus 1.00 , absence of correlation is indicated by 0 ).

The increase in oxygen consumption after the ingestion of from 54 to 102 grams (average 77 grams) of protein in five experiments on four patients with hypothyroidism is similar to the in- 
crease in oxygen consumption after protein (average 90 grams, range 45 to 223 grams) in 16 experiments on 9 normal individuals reported by Benedict and Carpenter (11) (Table VI, $a$ ).
These results are interpreted as demonstrating the presence of specific dynamic action of hexose in human hypothyroidism following total ablation of the normal thyroid gland. Although this spe-

TABLE VI

Comparison of specific dynamic action of protein in normals and in thyroidectomized patients

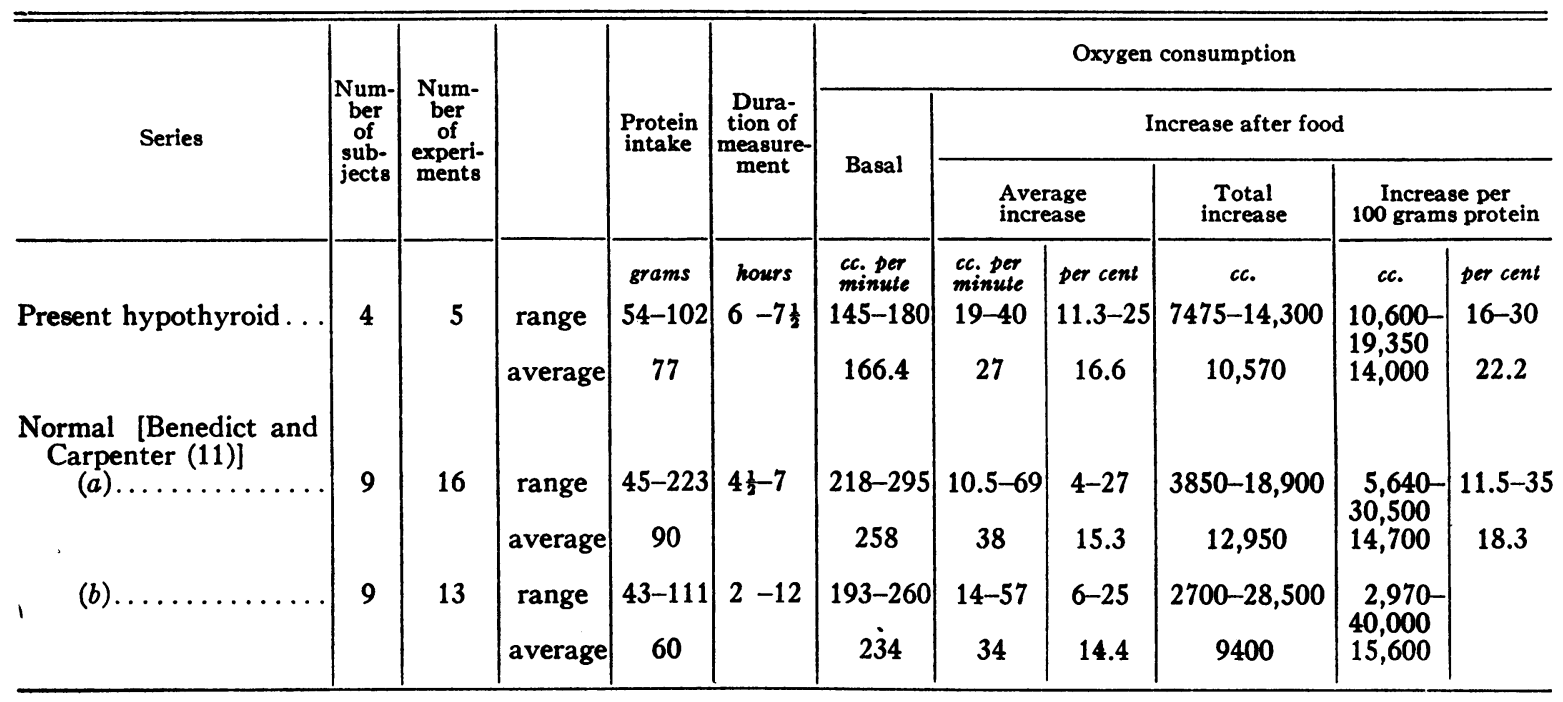

The increase in our experiments is also similar to that as estimated from the caloric increases reported in another series of thirteen experiments upon nine normal subjects by Benedict and Carpenter (11) (Table VI, $b$ ). There is considerable variation in the specific dynamic action of protein calculated in several different manners (Table VI), both among normal subjects and among our patients with hypothyroidism.

\section{SUMMARY AND CONCLUSIONS}

1. The specific dynamic action after the ingestion of 70 to 95 grams of carbohydrate was studied in eleven instances on nine patients at times varying from two to twenty-one months after total thyroidectomy. The average basal metabolic rate at the time of the eleven tests was minus 30.5 per cent. The oxygen consumption increased in each instance after the carbohydrate meal, the increase lasting from two to four hours. The average of the maximal increases over the basal oxygen requirements was $16 \mathrm{cc}$. of oxygen per minute or 10.1 per cent, and the average total increase was $1400 \mathrm{cc}$. per minute or 4.4 per cent for the average duration of the experiments ( 3 and $1 / 3$ hours). cific dynamic action appears in percentage to be approximately equal to, it is, on an absolute basis, somewhat less than the average of figures for normals taken from the literature.

2. The specific dynamic action after ingestion of 54 to 102 grams of protein was studied in five instances on four patients, at times varying from four to twelve months after total thyroidectomy. The average basal metabolic rate at the time of the five tests was minus 28.6 per cent. The oxygen consumption increased in each instance after the protein meal, the increase lasting at least six to seven hours. The average maximal increase was 29 cc. per minute (20 per cent of the basal oxygen requirement) and the total increase over the observed period ( 6 to 7 hours) was $10,570 \mathrm{cc}$. (16.6 per cent of the basal oxygen requirement) or $14,000 \mathrm{cc}$. per 100 grams of protein. These results are interpreted as indicating the presence of a specific dynamic action of protein in the totally thyroidectomized hypothyroid human subject. The extent of the specific dynamic action is within the range of normal as compared with values found in the literature. 


\section{BIBLIOGRAPHY}

1. Blumgart, H. L., Levine, S. A., and Berlin, D. D., Congestive heart failure and angina pectoris. The therapeutic effect of thyroidectomy on patients without clinical or pathological evidence of thyroid toxicity. Arch. Int. Med., 1933, 51, 866.

2. Blumgart, H. L., Riseman, J. E. F., Davis, D., and Berlin, D. D., Therapeutic effect of total ablation of normal thyroid on congestive heart failure and angina pectoris. III. Early results in various types of cardiovascular disease and coincident pathologic states without clinical or pathological evidence of thyroid toxicity. Arch. Int. Med., 1933, 52, 165.

3. Weinstein, A. A., Davis, D., Berlin, D. D., and Blumgart, H. L., The mechanism of the early relief of pain in patients with angina pectoris and congestive failure after total ablation of the normal thyroid gland. Am. J. M. Sc., 1934, 187, 753.

4. Davis, D., Weinstein, A. A., Riseman, J. E. F., and Blumgart, H. L., Treatment of chronic heart disease by total ablation of the thyroid gland. VII. The heart in artificial myxedema. Am. Heart J., 1934, 10, 17.

5. DuBois, E. F., Clinical calorimetry. XIV. Metabolism in exophthalmic goiter. Arch. Int. Med., 1916, 17, 915.

6. Weisz, R., and Adler, E., Das Verhalten der Standardumsatzsteigerung nach Zuckerzufuhr bei endokrinen Störungen. Klin. Wchnschr., 1922, 1 , 1592.

7. Grafe, E., Zur Pathologie und Therapie der sog "konstitutionellen" Fettsucht. Deutsches Arch. f. klin. Med., 1920, 133, 41.

8. Liebesny, P., Die spezifisch-dynamische Eiweisswirkung. Biochem. Ztschr., 1924, 144, 308.

9. Bernhardt, H., Zur Frage der spezifisch-dynamischen Wirkung der Nahrungzufuhr bei endokrinen Erkrankungen. Ztschr. f. klin. Med., 1924, 99, 149.

10. Serejski, M., and Jislin, S., Endokrine Störungen und spezifisch-dynamische Eiweisswirkung. Ztschr. f. d. ges. exper. Med., 1930, 69, 321.

11. Benedict, F. G., and Carpenter, T. M., Food ingestion and energy transformations with special reference to the stimulating effectoof nutrients. Carnegie Institute of Washington, Publication No. 261, 1918.

12. Plaut, R., Gaswechselunitersuchungen bei Fettsucht und Hypopysiserkrankungen. Deutsches Arch. f. klin. Med., 1922, 139, 285.

13. Plaut, R., Gaswechseluntersuchungsen bei Fettsucht. II. Mitteilung. Deutsches Arch. f. klin. Med., 1923, 142, 266.

14. Means, J. H., Aub, J. C., and DuBois, E. F., Clinical calorimetry. XX. The effect of caffein on the heat production. Arch. Int. Med., 1917, 19, 832.

15. Womack, N. A., and Cole, W. H., Effect of caffeine on basal metabolism. Proc. Soc. Exper. Biol. and Med., 1934, 31, 1248.

16. Baumann, E. J., and Hunt, L., On the relation of thyroid secretion to specific dynamic action. J. Biol. Chem., 1925, 64, 709.

17. Mansfeld, G., and Scheffer-Csillag, E., Beträge zur Physiologie der Schilddrüse. XI. Mitteilung. Die Rolle der Schilddrüse beim Zustandekommen der spezifisch-dynamischen Stoff wechselwirkung. Biochem. Ztschr., 1928, 200, 194.

18. Hertz, T., Der Einfluss der Schilddrüse und der Thymusdrüse auf den respiratorischen Grundumsatz und auf die spezifisch-dynamische Eiweisswirkung. Ztschr. f. Tier. u. Zucht. biol., 1927, 9, 1.

19. von Árvay, A., and Verzár, F., Die spezifisch-dynamische Wirkung bei Vitaminmangel. IX. Mitteilung. Inkretion und Avitaminose. Biochem. Ztschr., 1928, 192, 369.

20. von Ârvay, A., Die Wirkung von Thyroxin und Präphyson auf Grundumsatz und spezifisch-dynamische Wirkung nach Thyreoidaexstirpation und bei Avitaminose (Inkretion und Avitaminose $\mathrm{X}$ ). Biochem. Ztschr., 1929, 205, 433.

21. Dann, M., Chambers, W. H., and Lusk, G., Animal calorimetry. XLI. The influence of phlorhizin glycosuria on the metabolism of dogs after thyroidectomy. J. Biol. Chem., 1932, 94, 511.

22. Houssay, B. A., and Artundo, A., Extrait antéhypophysaire et action spécifique dynamique des Chiens Thyroprives et Thyro-Hypophysoprives. Compt. rend. Soc. de biol., 1933, 114, 392.

23. Grollman, A., The action of alcohol, caffeine, and tobacco on the cardiac output (and its related functions) of normal man. J. Pharmacol. and Exper. Therap., 1930, 39, 313.

24. Gephart, F. C., and DuBois, E. F., Clinical calorimetry. IV. The determination of the basal metabolism of normal men, and the effect of food. Arch. Int. Med., 1915, 15, 835. 